\title{
Gold in Ancient Palestine
}

\section{METHODS OF FABRICATION IN SUCCESSIVE CULTURES}

\author{
Janina Altman \\ Department of Chemistry, Technion-Israel Institute of Technology, Haifa, Israel
}

\begin{abstract}
In the wake of successive conquests, Ancient Palestine was subjected to a variety of cultural influences. Gold objects found in excavations there reflect these influences and bear witness to the importance of the area as a main trade route.
\end{abstract}

With centres of civilisation to both its east and its west, and as a natural passageway between these centres, Ancient Palestine was conquered repeatedly by invaders who left imprints on the land not only of their various beliefs and customs, but also of those of their trading partners. The gold artefacts which have been found in excavations in Ancient Palestine are therefore of particular interest in relation to the historical periods during which they were made.

\section{Gold in the Canaanite Period}

Although archaeological excavations along the coastal strip of Israel have unearthed graves furnished with pottery, weapons and very simple jewellery, only a few Early Canaanite gold artefacts have been discovered $(1,2)$. Thus, several simple round gold beads made from gold leaf and found in Azor, near Jaffa, are the earliest specimens of gold in this area. They date back to between 3200 and 2850 B.C. In addition, a small disc in repoussé technique has been found, along with gold beads, in a tomb in Beth Yerah near the Sea of Galilee. It dates back to between 2850 and 2650 B.C. and is decorated by punching with dotted circles and lines extending from the centre like the arms of a cross. The technique and motif have parallels among contemporary gold pendants from graves in Anatolia but there is no indication of whether the disc was an imitation produced by a local craftsman or an import.

There is archaeological evidence also, that gold was available for widespread jewellery production in Canaan from the second part of the Middle Bronze Age (1800 to 1500 B.C.), the period of the Hyksos domination of Canaan, until the Late Bronze Age (1500 to 1200 B.C.). The renewed Egyptian rule with the rise of the XVIIIth Dynasty (1580 B.C.) brought a prosperous period to the Canaanite city states, which sheltered the sanctuaries of their own gods side by side with those of the Egyptians $(3,4)$.

At the time, the main sources of gold were Egypt and Arabia. The Midianites, a nomadic semitic peo- ple who lived along the Red Sea coast, in the Gulf of Aqaba and in the north-west of the Arabian peninsula, were the chief agents in the gold trade with Arabia. They had acquired experience in mining and in the metallurgy of copper in Tymna - often mistakenly referred to as 'King Solomon's Mines'. Archaeological finds reveal that a number of techniques were used by the Canaanites in making jewellery from the gold obtained from the Midianites.

\section{Repoussé Work}

The Canaanites made a great variety of adornments, such as pendants or headbands for women, by beating gold into sheet or foil and ornamenting it with repoussé patterns. Thus, earrings consisting of thin gold plate bent round into hollow tubes and ornamented with ribbing have been found in Gezer and Tell el Ajiul (Beth Agilim, near Gaza). Different

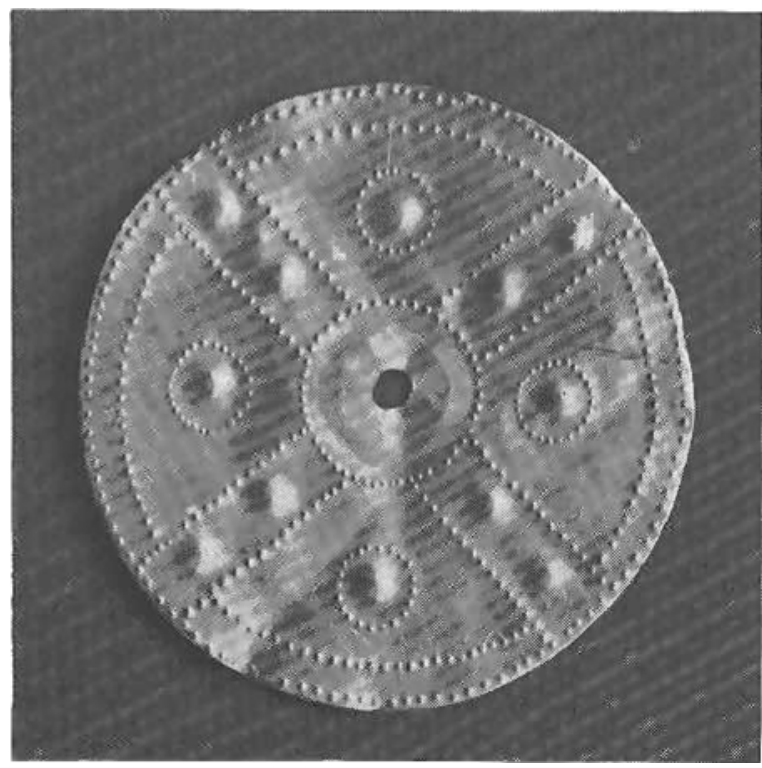

Early Canaanite disc-shaped gold ornament with pierced centre and repoussé decor from Beth Yerah, near the Sea of Galilee (between 2850 and 2650 B.C.)

Israel Museum, Jerusalem; Photograph David Harris 


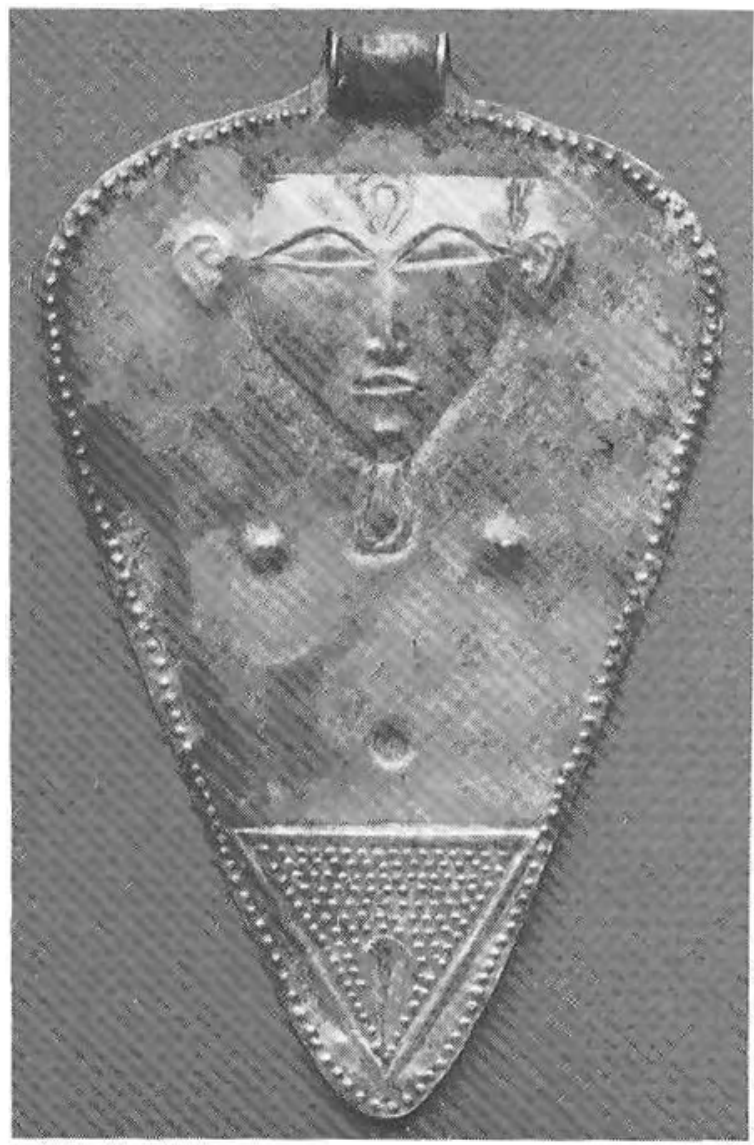

This Woman plaque-pendant from Tell el Ajjul is a good example of Canaanite repoussé work. It represents Astarte, known to all semitic peoples in the Orient as the goddess of fertility. The face is embossed while the bordex and the lower part of the plaque, which shows schematically the fertility attributes of the goddess, have been punched from the back. The combination of an Egyptian head with the stylized body is undoubtedly Canaanite in origin (1600 to 1400 B.C.). Similar plaques have been found in Ugarit Rockefeller Museum, Jerusalem; photograph David Harris types of beads, all of them hollow, either impressed, granulated or plain were executed in repoussé. The impressed beads recall specimens from the Royal Tombs at Ur and at Byblos and have counterparts at Alalakh but the granulated ones found in Tell el Ajjul have no parallel elsewhere. Fluted and plain globular beads have also been found in Shechem and Megiddo, the latter being similar to those made in Egypt and in Byblos from the XIth Dynasty onwards.

\section{Soldering}

The crescent-shaped gold earrings found in the Tell el Ajjul hoards (1800 to 1600 B.C.) reveal the use of a new technique, in which thin sheets of gold were soldered back to back, giving an air of solidity to objects which are really hollow. In order to complete the decor, clusters of granules were attached to bosses on the surface. The gold pendants of sheet metal cut in the shape of a hawk and decorated by granulation, which are exhibited in the Rockefeller Museum and in the British Museum, have been fabricated in a similar manner.

\section{Gilding}

Gold foil was used by the Canaanites for gilding bone and bronze objects. Gilded wooden objects were probably also made but have not survived. Whereas in Egypt statuettes of gods were cast in pure gold, those found in Canaan were cast in bronze with only the face overlaid with gold. A small statuette of Hathor (fourteenth century B.C.) has been found in a Canaanite temple in Beth Shean. Hathor was an Egyptian goddess adopted by the Canaanites and called Baalat (Lady). The gilding technique was simple because of the ductility of the metal, the thin gold

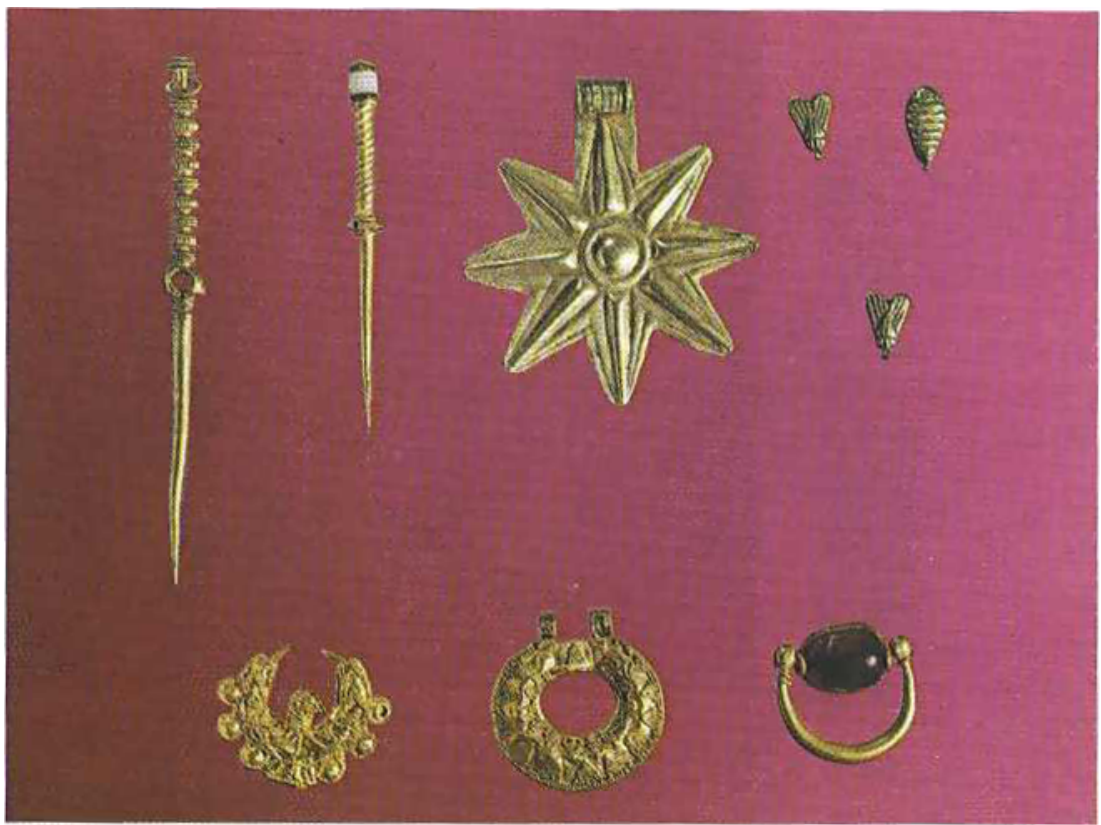

Toggle-pins, ring set with lapis lazuli, star pendant, fly-amulets and crescent-shaped earrings from the "Treasure of the Cenotaph' in Tell el Ajjul. The toggle-pins and fly-amulets were cast, while the hollow earrings were made from gold sheets soldered back to back and decorated by granulation (1800 to 1600 B.C.)

Photograph by courtesy of the Rockefeller Museum, Jerusalem 
sheets being applied to objects and worked into shape by hammering. Other statuettes gilded in this manner have been found in Megiddo and in Ugarit.

\section{Casting}

When gold was cast, it was melted in closed crucibles to prevent the loss of any of the precious metal. Such crucibles, dating from the Late Canaanite or Early Israeli periods (5), have been discovered in several places in Palestine. The molten metal was run into hard stone moulds in which the patterns of the required objects had been carefully carved. The earliest gold objects were cast in open moulds but later two-piece moulds came into use which were provided with holes or small escape channels so that the excess metal could flow out. Proper fit of the two halves was ensured by mortises and tenons. Where the cast object was to be suspended, a pin was placed through the mould which ensured that the final casting was pierced.

Gold toggle-pins, the forerunners of the modern safety-pins and fibulae used in fastening garments together, are very interesting items in the Tell el Ajjul hoards. They have no parallel in Egypt before the appearance of the Hyksos, although bronze and gilded bronze toggle-pins have been found in Gezer and Naharya. Each toggle-pin consists of three parts: the hilt which was twisted or ribbed, and either without head or knobbed, the central part which was pierced by a hole and the lower smooth part which was stuck through the garment.

The Canaanite gold work was strongly influenced in techniques and style by its Egyptian counterpart $(6,7)$ but is nevertheless clearly characterized by its own motifs and Canaanite religious beliefs.

\section{Phoenician Goldware}

The Phoenicians (8) as a people cannot be differentiated from the general mass of Canaanites until the later half of the second millennium B.C. They lived in the northern part of Palestine and on the coastal strip of Lebanon. A brief description of Phoenician gold craft is worth including here because it had a definite and direct influence on developments in neighbouring Palestine, mainly during the Israeli period. As the natural resources of their country were meagre, the Phoenicians developed maritime trade at an early date and maintained close commercial relations with the Minoans and Mycenaeans in the west and with the Assyrians in the east. Thanks to these contacts, they became innovators in metal work, especially in precious metals.

Their gold was obtained from Ethiopia, Arabia and Asia Minor. Remains of smelters have not been found but hammers, tongs and other metal-working tools are depicted on funerary stelae. They learnt

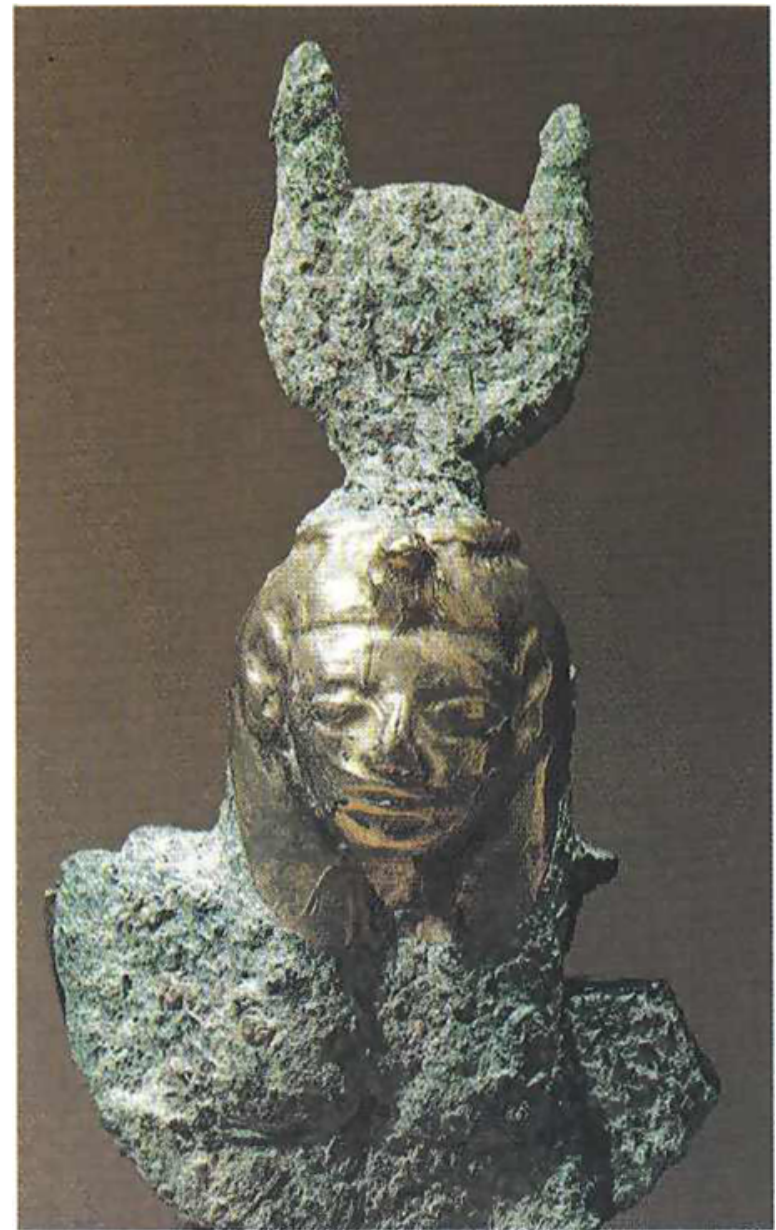

Bronze statuette of the goddess Hathor with gold foil overlay on the face. Beth Shean excavations, Late Canaanite period (1500 to 1200 B.C.)

Photograph by courtesy of the Israel Museum, Jerusatem

goldsmithing partly from Egypt and partly from the Mycenaeans and their style was characterized by a mixture of Egyptian, Assyrian and Aegean motifs of which cherubim, palmettes and flowers are typical elements. The Phoenicians were experts in the manufacture of beautiful gold, silver and gilded silver vessels. Gold bowls and plates from the sixteenth to the fourteenth centuries B.C. were found by C. F. A. Schaffer in an Ugarit excavation. The bowl illustrated here is executed in repousse technique, with an embossed and chased scene of a hunt from a chariot.

The Phoenicians also excelled in the manufacture and design of jewellery, mainly of gold. Necklaces, earrings, bracelets and pendants of all kinds, executed in repoussé and decorated by embossing and granulation but not with filigree, have been found. They served as prototypes for Etruscan jewellery. It is difficult to distinguish eastern from western styles and the Phoenicians being adventurous travellers and active traders, the place of the finding does not necessarily indicate the origin of the object. 


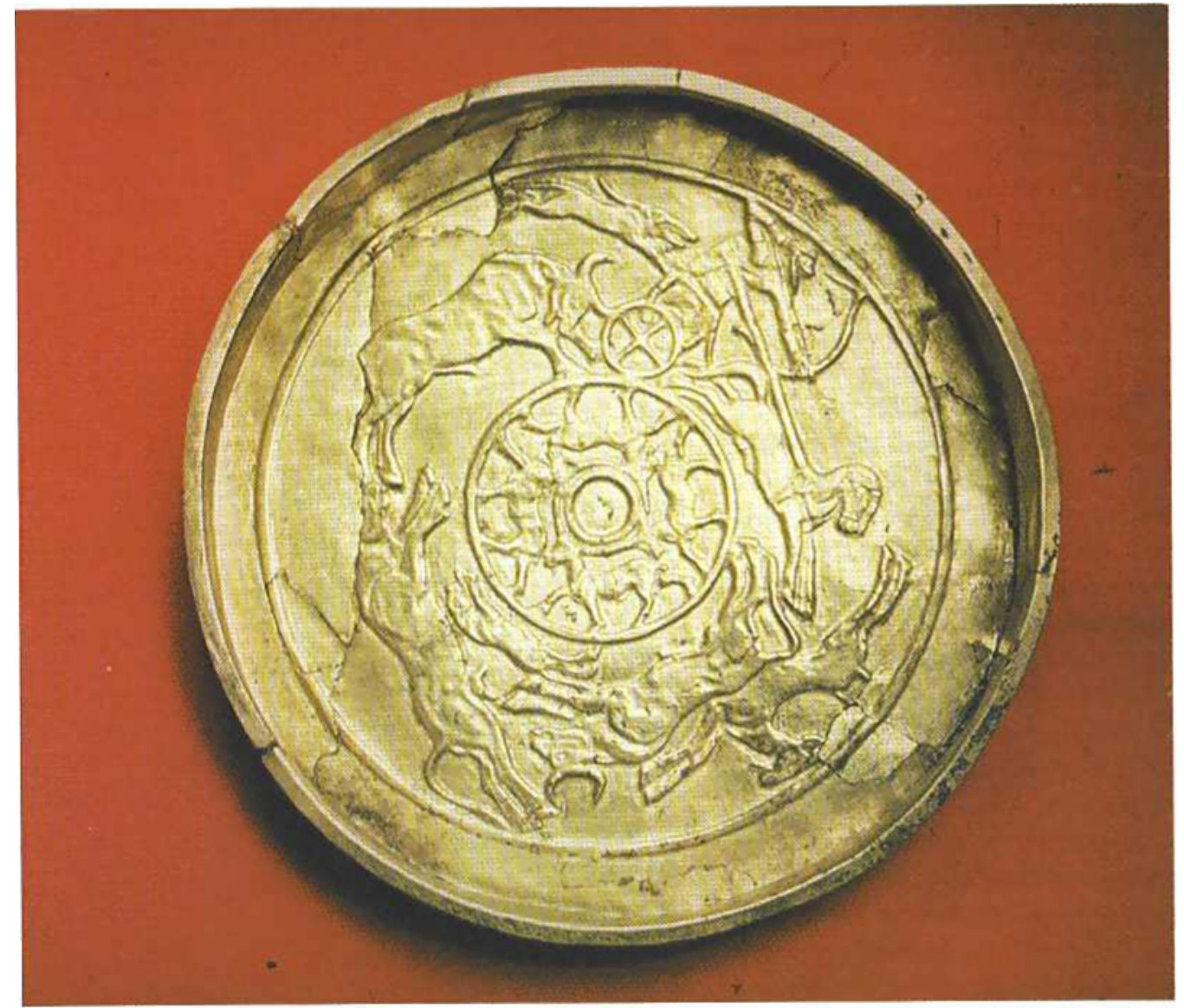

This Phoenician bowl from Ugarit has been dated to the fifteenth or fourteenth century B.C. The embossed hunting scene reveals the Assyrian influence with the archer, a Minoan element with the running bulls and the Egyptian influence with the rather static animals in the centre Photograph by courtesy of the Musée du Louvre, Paris

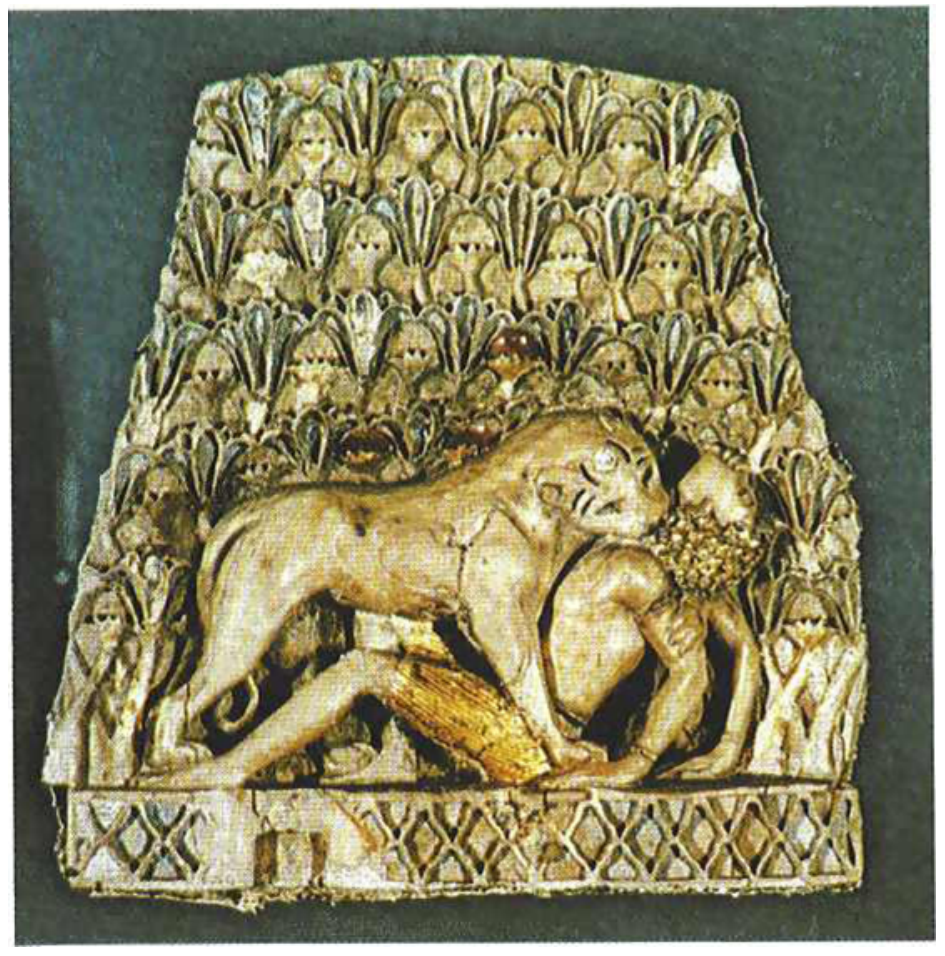

Gilding was applied to metal, wood and ivory and the latter two were used to decorate walls and furniture. Wooden objects have not survived but some beautiful examples of gilded ivory have been found. A pair of sculptures from a single piece of furniture of Phoenician manufacture was found in the sludge at the bottom of an ancient well in the north-west palace of Ashurnasirpal at Nimrud. It had probably been taken there by the Assyrians as loot from a Phoenician city.

Phoenician curved ivory panel from a piece of furniture, representing a lioness devouring a negro. Gilding provides an element in the colour composition (eighth century B.C.)

Photograph by courtesy of the Trustees of the British Museum, London 


\section{Gold in the Israeli Culture}

In the Bible, gold is the most frequently mentioned of all metals but almost no gold objects have been found from the Israeli period of Palestine (1200 to 587 B.C.). Nevertheless, crucibles have been unearthed in Gezer and in Akko so that there is no doubt that the goldsmith's craft was practised by the Hebrews. To date, however, only a few hoards have been discovered, in Gezer, Akhsiv and in Beth Shemesh, and they have consisted of relatively simple gold earrings, beads of various sizes and shapes, similar to those from the previous Canaanite period, and discs executed in repoussé with dots and holes apparently intended for sewing onto garments.

In Gezer, two gold ingots have been found, one is a circular disc, $6.4 \mathrm{~cm}$ in diameter and weighing $348 \mathrm{~g}$, and the other is a bar weighing $858 \mathrm{~g}$ and $25.7 \mathrm{~cm}$ long and $0.64 \mathrm{~cm}$ thick. The latter is $2.9 \mathrm{~cm}$ wide at one end and tapers down to $2.3 \mathrm{~cm}$ at the other, producing a tongue-like shape that recalls the ins (lashon) or 'tongue' of gold ('wedge' in the English version) which Achan stole from the fallen Jericho (Jos., 7:21). The coincidence suggests that this was a usual form for gold bars used for trade between 1500 and 1000 B.C. According to analysis the gold is very pure.

The Bible mentions Arabia, Sheba, South Arabia and Ophir as sources of gold. The geographical location of Ophir remains the object of much speculation. American and Saudi geologists suggested in 1976 that it may have been situated between Mecca and Medina (9). However, this finding can easily be disputed on the basis that, had this been the case, overland expeditions would have been possible, and probably preferred, from Israel to Arabia and back.

Different methods are described in the Bible for working in gold. Casting was probably employed for making the Golden Calves (Ex., 32:4; I Kings, 12:28). Gold sheets were used to make gold wire or thread:

'And they did beat the gold into thin plates, and cut it into wires to work it in the blue, and in the purple, and in the scarlet, and in fine linen, with cunning work.' (Ex., 39:3)

The cherubim and the gold candelabrum for the Tabernacle were made of beaten gold. The cherubim

Gold ring with amazonite seal bearing an inscription in ancient Hebrew letters (eighth century B.C.)

Photograph by courtesy of the Israel Museum, Jerusalem were made of one piece, together with the lid of the Ark and the candelabrum was beaten in one piece out of talent gold (Ex., 25:17 to 19). Also, gold overlay was applied to the surrounding wooden boards in the Tabernacle.

In Egypt, gold mining was state run and goldsmiths either bought their material from the state or worked in a temple under the supervision of priests. In contrast, the work in gold for the Tabernacle was performed by a man specially chosen from outside the priest caste:

'See, I have called by name Bezaleel the son of Uri, the son of Hur, of the tribe of Judah;

And $I$ have filled him with the spirit of God, in wisdom, and in understanding, and in knowledge, and in all manner of workmanship,

To devise cunning works, to work in gold, and in silver and in brass,...' (Ex., 31:2 to 4 ).

Later, large quantities of gold were concentrated in King Solomon's hands and were dedicated to the construction of the First Temple in 967 B.C. (I Kings, $6: 20$ to $35 ; 7: 46$ to 51 ) and of his palace. During King Solomon's reign, the economic and cultural life of Israel reached a zenith, owing to the good mutual relations with neighbours, mainly with Hiram the Phoenician ruler of Tyre. Hiram, at Solomon's request, provided materials and workmen to help build the Temple in Jerusalem (I Kings, 5:1 to 18; 7:13 and 14). The Temple of Solomon was plundered on several occasions and nothing has remained of its splendours. The only immediate source of comparison in styles and subjects, according to J. W. and G. M. Crowfoot (10), is to be found in the excavations of Samaria, where remains of the House of Ivory' of Ahab (876 to 822 B.C.) have been found. Several small ivory plaques from Ahab's palace, decorated with palmettes and coloured with insets of glass and gold leaves, are exhibited in the Israel Museum in Jerusalem and serve as an indication of what was accomplished with gold-overlaid wood in the Temple of Solomon.

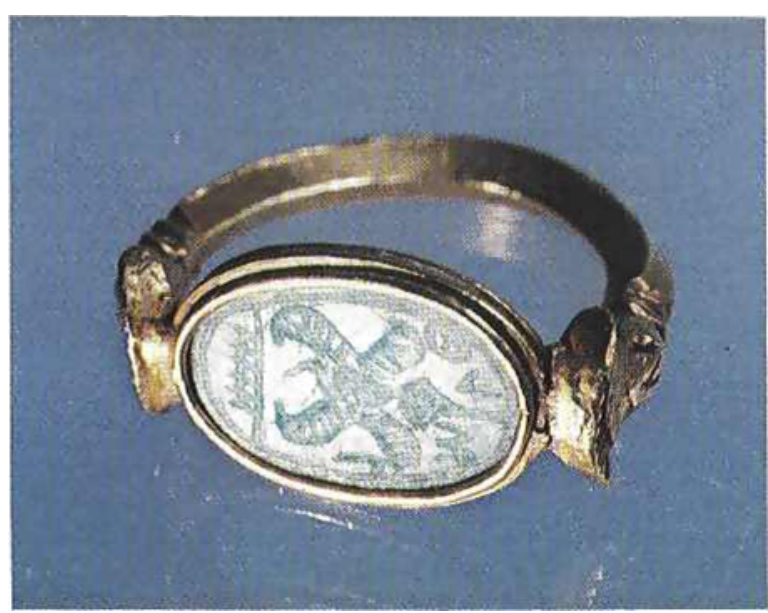




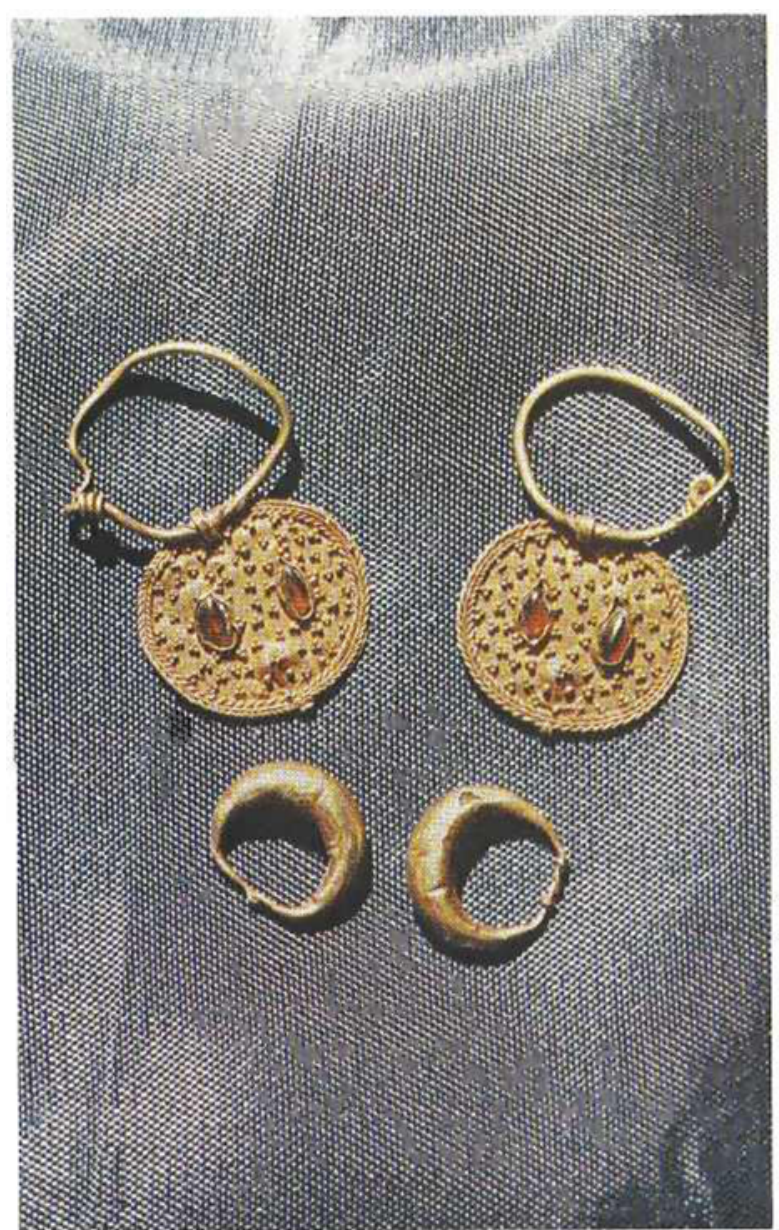

Nabataean earrings from the cemetery of Mampsis. The small pair is made of thin gold sheet and is hollow. The large pair consists of dises of gold sheet decorated on the edge with a plaited wreath in filigree, with granulated clusters on the surface and two bezel-set red stones. The plaited wreath is a common element in many objects of Nabataean origin, such as pottery, and supports the assumption that these pieces were produced by Nabataean goldsmiths between the first and the third century A.D.
The impression gained from the Bible and from modern research is that the use of gold for decoration was reserved for royalty and cultic purposes. Hebrew inscriptions on gravestones of the eighth and seventh centuries B.C. indicate that it was not the custom to put objects of value into the burial caves (11) and there seems to have been very little gold in private hands. The main accumulation of gold vessels and treasures was in the Temple and an indication of the size of this collection is given in a description of some of the treasures returned by Cyrus, 50 years after the destruction of the First Temple (586 B.C.):

\footnotetext{
'...thirty chargers of gold, a thousand chargers of silver, nine and twenty knives,

Thirty basons of gold, silver basons of a second sort four hundred and ten, and other vessels a thousand.

All the vessels of gold and silver were five thousand and four hundred.' (Ezra, 1:9 to 11)
}

Some idea of the size of the golden table and the shape of the golden candelabra in the Second Temple is given by Josephus Flavius in 'The Jewish War', where he describes the triumphal procession of Titus in Rome (70 A.D.):

'It is impossible to give a satisfactory account of the innumerable spectacles, so magnificent in every way one could think of, whether as works of art or varieties of wealth or rarities of nature; almost all the treasures that have ever come one at a time into the hands of fortune's favourites - the priceless marvels of many different peoples - were brought together on that day ... Masses of silver and gold and ivory in every shape known to the craftsman's art could be seen, not as if carried in procession but like a flowing river .. Most of the spoils were heaped up indiscriminately, but more prominent than all the rest were those captured in the Temple at Jerusalem - a golden table weighing several hundredweight, and a lampstand similarly made of gold but differently constructed from those we normally use. The central shaft was fix ed to a base, and from it extended slender branches placed like the prongs of a trident, and with the end of each one forged in to a lamp: these numbered seven, signifying the honour paid to that number by the Jews."

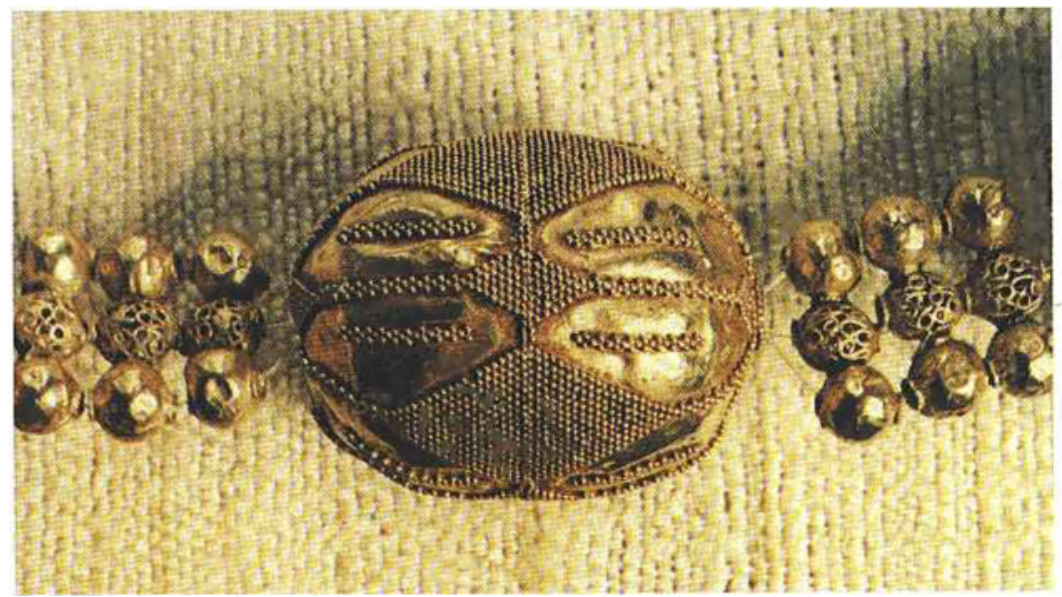

This detail from a gold necklace found in Cesarea illustrates the high degree of craftsmanship attained by the Islamic goldsmiths of the eleventh century A.D.

Photograph by courtesy of the Israel Museum, Jerusalem 


\section{The Persian, Greek, Roman and Byzantine Periods}

Relatively little jewellery has been found from the periods in which Palestine was successively a part of the Persian, Greek, Roman and Byzantine empires, as compared with the amounts found in Canaanite hoards. The objects discovered well reflect the characteristic features of their period and their style is strongly reminiscent of that of the dominant civilisation of the time. The fact that no moulds have been found, however, raises doubts as to whether gold artefacts were actually produced locally.

A Persian gold earring from the fourth century B.C. has recently been found in Ashdod, which depicts a wild goat in the Achaemenid style. Such earrings were common in Persia and many parts of the Persian Empire and moulds for similar objects have been discovered in Egypt and in Byblos.

A pair of earrings from the Roman period (second or third century A.D.), in the shape of a basket entirely made in delicate filigree work, has been found in Hamat Tiberias. The Hellenistic influence is pronounced in this specimen. A gold diadem found in a tomb in Kfar Giladi and a pair of earrings from Jerusalem illustrate polychrome and fretwork techniques. A coloured semi-precious stone is the main decorative element, whereas the gold frame is of simple repoussé work. Similar earrings have been found in Europe. Small magical gold plaques from a tomb in Jaffa, used during the process of mummification, were also executed in simple repoussé technique, having incised lines as the main decorative element.

Jewellery decorated with Christian themes appeared in Palestine in the Byzantine period (sixth century A.D.). One of the best examples was found in the excavations at the Temple Mount. It is a gold ring to which is attached a decorative structure which probably represents the grave of Jesus Christ.

\section{Nabataean Jewellery}

The Nabataeans were Arabic tribes who had settled in Transjordania and the central Negev at the end of the fourth century B.C. They lived there, though discontinuously, for 500 years. Their successive periods of rise and fall were associated with the periods of stabilization and decline of the Hellenic, Roman and Byzantine empires. They were mainly occupied with the caravan trade through the stretches of desert between Syria and Arabia, transporting goods from the Mediterranean to the Red Sea, and they succeeded in transforming the road stops in the desert into flourishing cities in which Arabian gold concentrated. Some of the Nabataean cemetries have remained undisturbed by grave-robbers and most of the tombs until the middle of the third century contain gold jewellery. According to the Greek religious custom adopted by the Nabataeans, the men were buried with a coin in the mouth or with a pendant, so that they would have payment ready for Charon for the crossing of the River Styx at the entrance to the Underworld. The women were buried with two pairs of earrings. Those of one pair were small and made of thin gold sheet fabricated into tubular boat shapes. Such earrings were known in the Near East from the second millennium B.C. These simple earrings were possibly given to the women in their youth.

A common motif in Nabataean work is a plaited wreath which together with granulation was extensively used to decorate gold jewellery. Of particular interest are pendants in the form of a dolphin made by casting which have been found in three different tombs. The dolphin was venerated by the Nabataeans as a merchant god and the pieces were probably worn as amulets.

\section{Gold in the Islamic Culture of Palestine}

From the seventh century A.D. onwards, the Islamic cultural element was added to those of the many peoples who lived in Palestine. An example of the use of gold in the Early Islamic period is illustrated by mosaics in the Dome of the Rock (the Mosque of Omar), built by Abd-al-Malik at the end of the seventh century (12). There are beautifully rendered fruit-bearing trees, palmettes, candelabra and acanthus scrolls - inspired by a hybrid of Hellenistic, Roman and Sassanian sources. The tesserae forming the gold background, vary in size from 0.25 to $1 \mathrm{~cm}^{2}$ (13). They are set in plaster, forming regular horizontal courses one above the other. Each is fixed with its axis not at right angles to the surface of the wall but at an angle of about 30 degrees. The golden surface is thus not smooth, for each course of tesserae has a sloping face, with several courses together making a zig-zag line. The tesserae have fallen in many places and imitations in paint have been made over the years, but fragments of the original mosaic have survived on one of the jambs of the eastern window of the drum and on the outer walls of the shrine.

Few Islamic gold jewellery pieces have been found which date from this period. However, recently a beautiful necklace of granulation and filigree work from the Late Islamic period (early eleventh century) was discovered in a jar hidden in the Arabic occupation layer in Caesarea. The necklace consists of six large round beads of sheet gold ornamented by granulation, together with round and biconical beads in very fine filigree work. The large beads are linked together with three rows of small beads, some are made of sheet gold and others in filigree. The quality of the piece is an indication of the high degree of skill attained by the Islamic goldsmiths. 
Owing to the restrictions of the Koran - the Holy Book of Islam, which preaches modesty and restraint in the use of precious metals, most of the metallic vessels produced during the early Islamic period were of cheap materials like brass or bronze. But artists from the Mosul school (about 1250 A.D.) introduced gold and silver for inlaying. Their brass and bronze vessels inlaid with gold, silver and copper, are works of astonishing delicacy which were imitated all over the Islamic world and also became a source of inspiration for the Venetian school. Several examples of these gold inlaid vessels are to be found in the L.A. Mayer Memorial for Islamic Art in Jerusalem.

This survey of some forty centuries of goldsmithing in Ancient Palestine ends with the advent of the Crusaders which terminated the Late Islamic period.
The style and methods of manufacture of the gold objects found in Palestine are revealing of the great variety of cultural influences that successively dominated the area. Quite remarkably, however, through the ever changing pattern of culture and customs, gold remained the medium selected as most fitting for the portrayal of religious beliefs.

\section{Acknowledgements}

The author wishes to thank the following persons for their help in obtaining photographs: $\mathrm{Mr}$. David Maestro and Mrs. Alisa Polachel of the Technion-Israel Institute of. Technology, Mr. Levi Itzchak Rachmani of the Israel Department of Antiquities, Mrs. Irene Levitt of the Israel Museum, Professor Abraham Negev of the Institute of Archaeology at the Hebrew University of Jerusalem, Mrs. Sarah Irmay, Mrs. Doreen Walsh and Mrs. Charlotte Diamont. Thanks are also due to Professor Vera Rohrlich of the Technion-Israel Institute of Technology and Professor Benno Rothenberg of the Ha'aretz Museum for valuable discussions.

\section{References}

1 A. Negev, 'Archaeological Encyclopaedia of the Holy Land', Weidenfeld and Nicholson, London, 1972

2 W. F. Albright, 'The Archaeology of Palestine', Penguin Books Ltd., Harmondsworth, 1960

3 O. Negbi, in 'Studies in Mediterranean Archaeology', Paul Astrom, Götenberg, 1970

4 R. Rosenthal, 'Jewellery in Ancient Times', Cassel Ltd., London, 1973

5 R. A. S. Macalister, 'The Excavation of Gezer', John Murray, London, 1912, vol. 2, p. 260 and vol. 3, pl. CXXXI

6 T. G H. James, Gold Bull., 1972, 5, (2), 38-42
7 P. M. Roberts, Gold Bull., 1973, 6, (4), 112-119

8 D. Harden, 'The Phoenicians', Penguin Books Ltd., Harmondsworth, 1971

9 Anon., Min. Annu. Rev., 1978, 517

$10 \mathrm{~J}$. W. Crowfoot and G. M. Crowfoot, 'Early Ivories from Samaria', Palestine Exploration Fund, London, 1938

11 S. M. Paul and W. G. Dever, 'Biblical Archaeology', Keter Publishing House, Jerusalem Ltd., Jerusalem, 1973

12 E. T. Richmond, 'The Dome of the Rock in Jerusalem', Clarendon Press, Oxford, 1924

13 G. Bustacchini, Gold Bull., 1973, 6, (2), 52-56 